MAGISTRA ANDALUSIA

e-ISSN 2656-6230

Jurnal Ilmu Sastra

\title{
ANALYSIS OF POSTMODERNISM IN ORANG-ORANG BLOOMINGTON NOVEL BY BUDI DARMA
}

\section{ANALISIS POSTMODERNISME DALAM NOVEL ORANG- ORANG BLOOMINGTON KARYA BUDI DARMA}

\author{
Muhsyanur \\ Universitas Puangrimaggalatung \\ Gedung A1-03, Jalan Puangrimaggalatung No. 27 Sengkang, \\ Kab. Wajo-Sulawesi Selatan \\ Telepon (0485) 21595, HP. 082345358661 \\ Email: muhsyanursyahrir85 @gmail.com \\ https://doi.org/10.25077/majis.2019.v1i2.13
}

\begin{abstract}
The purpose of this study was to describe aspects and characteristics of postmodernism in the novel Orang-orang Bloomington by Budi Darma. This study uses a descriptive approach. The method, which is collecting data, reading, and analyzing data. Based on the results of the study, the aspects of postmodernism were found, namely parody and camp, while the characteristics of postmodernism were found, namely the aspect of reducing admiration for science, capitalism, and technology, and shifting dominance.
\end{abstract}

Keywords: postmodernism, parody, camp, science, capitalism and technology

\begin{abstract}
Abstrak
Tujuan dari penelitian ini adalah untuk menggambarkan aspek dan karakteristik postmodernisme dalam novel Orang-orang Bloomington karya Budi Darma. Penelitian ini menggunakan pendekatan deskriptif. Metode, yaitu mengumpulkan data, membaca, dan menganalisis data. Berdasarkan hasil penelitian, ditemukan aspek postmodernisme, yaitu parodi dan camp, sedangkan karakteristik postmodernisme ditemukan, yaitu aspek mengurangi kekaguman terhadap sains, kapitalisme, dan teknologi, dan pergeseran dominasi.
\end{abstract}

Kata kunci: postmodernisme, parodi, kemah, sains, kapitalisme dan teknologi

\section{INTRODUCTION}

Literary work is a reflection of the the power of imagination and creation that author about life and life combined with is supported by his experience and 


\section{Jurnal Ilmu Sastra}

observation of life. One expert, the preface of this novel, that the stories in Djojosuroto (2002: 17) says that the this novel are not subject to abstract nature of literature / literary work is a form and result of creative arts work whose object is human and life by using language as its medium.

The statement above implies that humans use literature as a means to express ideas, experiences, thoughts, etc., so that it can be concluded that literary works are very beneficial for humans or readers. Wellek and Werren (1990: 109) states that literature has a social function or "benefit" that is not entirely personal. So, the problem of literary study implies or is a social problem: the problem of tradition, conventions, norms, types of literature (genres), symbols, and myths.

One of the phenomena that depicts the culture of the world today is modernism. Postmodernism is one of the schools of thought that contradicts the modern school and flows in all fields. As stated by Hutchheon (2004: 1) that postmodern is a school of thought which becomes a new paradigm as an antithesis which is considered to be a failure and is no longer relevant to the development of the current era.

Indonesian literature also cannot escape the symptoms that arise from postmodern thinking. One work that has a tendency to be influenced by postmodern charmers is the novel Orang-orang Bloomington (2004) by Budi Darma. This study specifically addresses the novel Orang-orang Bloomington. As written in things, but tell about the emotional upheaval of the characters in them and humanistic and meaningful issues in a plural global environment. Based on this, the two things that are the focus of the problem in this paper are the postmodernism aspects revealed in the "Orang-orang Bloomington" novel and the characteristics of postmodernism in the novel "Orang-orang Bloomington" by Budi Darma.

There are several theories about postmodernism developed at this time. etymologically postmodern consists of two words, namely post and modern. The word " post " means later of after and modern. Besides that, according to the other postmodernism camp " post " means beyond death of modernism (Muzairi, 2009: 148). In thermonologies a postmodern critique of modern society and its failure to fulfill its promises. Har a fiah postmodernism can be defined as a period after the modern period, can be interpreted as an era that gave birth to human beings with thoughts that may be against the conceptions held by modernism itself.

Postmodernism promises an understanding of a new world intentionally human thinking about the development of an increasingly fluid and flexible world. Postmodern tends to criticize everything associated with modernity, namely the accumulation of 


\section{Jurnal Ilmu Sastra}

experience of western civilization (Aceng, 2011: 104).

In addition, Nath (2014: 27) says the essence of postmodernism is view of reality. According to postmodernism, the apparent realities of are only social constructs and the results of these are not static but subject to change. It emphatically believes that for the formation of ideas and belief, the role of language, power, relations and motivations are immense. This approach of thought does not believe between male and female, straight and gay, straight and gay, white and black or imperial and colonial. It does not believe any absolute truth. Rather it believes that reality is plural relative and consistent. The description of reality is dependent on persons and their nature who describe it. Moreover, the person who is perceive it and thus this description is subjective. Many cultural fields including religion, literary etc. are influenced by postmodernism.

Based on some understanding, it can also be interpreted that postmodernism is an understanding that criticizes and surpasses the values and views carried by the previous era, especially on modernism which is considered a failure and as a reaction to rebellion and criticism of the promise of modernism. In the opinion of some experts, the 20th century can be divided into two distinct periods, one characterized by postmodernism. Postmodernism is considered a response to modernism and therefore both are two aspects of the same movement.

There are several main differences between modernism and postmodernism. Modernism and postmodernism have different ways of approaching life. Modernism represented various cultural movements in the late 19th and early 20th centuries. Modernism includes reform movements in art, reading, music, architecture, and applied arts. This movement is also marked by efforts to involve science and technology into every aspect of life. Modernism brought reform in all areas of life including philosophy, trade, art, and literature with the help of technology. Postmodernism means, 'after modernism'. This movement is a reaction to modernism influenced by the disappointment caused by the Second World P groaned.

Setiawan (2018: 28) concludes that postmodernism is a new idea that rejects or even includes the development of an existing idea about the theory of thought in the past, which is modernism that tries to criticize modernism which is considered to have failed and is responsible against the destruction of human dignity; it is a shift in science from modern ideas to a new idea brought about by postmodernism itself .

\section{Domains of Aspects Postmodernism}

Some central aspects associated with postmodernism according to Jean Francois Lyotard (Sarup, 2007: 226) . 


\section{Jurnal Ilmu Sastra}

First, deletion the boundary between art and everyday life. Second, there is no difference between low art and high art, popular art (popular art) and pure art (fine art). Third, ecskleticism is zero from contemporary general culture: for example, people listen to reggae music in America, watch coboy movies in Arabic, eat Mc Donald for lunch and local cuisine for dinner, use Paris perfume in Tokyo and retro clothes in Hong Kong . Fourth, parody is a form of dialogue, namely one text meets and has dialogue with other texts. The purpose of the parody is to express feelings of satisfaction, displeasure, discomfort regarding the intensity of the style or past work referred to. Fifth, pastiche is a dream or wishful thinking, pure imitation without any pretense. Text pastiche texts imitate the past to lift and to appreciation. Sixth, irony is an event or situation that is contrary to what is expected or that should have happened, but has become a letter of destiny. Seventh, It is very playful which means that the text or words are deliberately mocked to create a dramatic atmosphere. Eighth, kitsch is a low-taste, low-taste art that reproduces styles, shapes and icons or shifts the emphasis from form or style. Ninth, camp is harboring identity and retention. One model of aesthetic, namely one way of seeing the world as an aesthetic phenomenon. Example: use of art noveau and art deco elements in buildings now. Tenth. transformation reality into images.
Eleventh, the transformation of time is now a series.

\section{Characteristics of Postmodernism}

According to Jean Francois Lyotard (Sarup, 2007: 222) that the characteristics of postmodern include; first, want great respect for nature. Second, emphasizing the importance of language in human life. Third, reducing admiration for knowledge, capitalism and technology. Fourth, accepting the challenges of other religions against the religion of the donors. Fifth, accept and be sensitive to new religions (other religions). Sixth, shifting the dominance of whites in the western world. Seventh, encourage the rise of oppressed groups, such as racial groups, excluded social classes. Eighth, foster awareness of the importance of radical interdependence of all parties in ways that can be thought of.

\section{METHOD}

The subject of this research is the Bloomington People's novel by Budi Darma. The steps taken in this study are as follows. First, collecting data, both primary and secondary data needed in this study. Second, make a reading of the data collected. Third, do a descriptive analysis by describing the aspects and characteristics of postmodernism.

\section{FINDING AND DISCUSSION}

Novel "People Bloomington" by Budi Darma is a cultural literary nonfiction is non-fiction works of literature 


\section{Jurnal Ilmu Sastra}

that have been tackled. The novel is on categorizing it as a social novel contains many elements of postmodernism. The existing reality regarding modernism in the world of art has an extraordinary challenge when faced with a new philosophy, namely postmodernism. In contrast to modern philosophy which seeks to absolve truth only on the basis of ratio and science, postmodernism actually gives a statement that there is no truth that is absolute and universal.

The "Bloomington People" novel is a collection of short stories consisting of seven stories, namely an anonymous old man, Josua Karabish, M Family, Orez, Yorrick, Ny. Elberhart, and Charles Lebourne. This collection of stories was written in the late 1970 s by raising stories about the character's emotional upheaval and various humanitarian issues in dealing with the surrounding community.

\section{Aspects of Postmodernism in the Novel Orang-orang Bloomington by Budi Darma}

Based on the eleven aspects of postmodernism mentioned above, there are several aspects of postmodernism found in the collection of stories of "Bloomington People". One aspect that is found is the parody. The parody is one form of dialogue in the form of one text meeting and dialogue with other texts in order to express feelings of satisfaction, displeasure, discomfort with regard to the intensity of the style or past work referred to. Parodies are also formed from the dramatizing nature of events that are built from human feelings. Allusions in parodies are used by some people to explain things that are not ignored by most people. That is in the quote as follows.

"Sudah lama saya tinggal di gedung raksasa yang memuat dua ratus apartemen ini, dan mungkin sayalah satu-satunya yang hidup sendirian tanpa anak dan istri. Selama ini saya tidak pernah terganggu. Meskipun saya tidak pernah mempunyai cita-cita untuk mempunyai anak..." (Darma: 2004: 55).

"I've been living in a giant building that contained two hundred apartments, and maybe I'm the only one who lives alone without a child and wife. During this time I have never been disturbed. Even though I never had an aspiration to have children ... "(Darma: 2004: 55).

The quote above tells the character who lives in an apartment with residents who mostly have many children. The children make a commotion every day so they disturb other residents, especially for those who have no family. It is said that the character seems to be accustomed to living with children which is sometimes annoying. Nevertheless he managed to 


\section{Jurnal Ilmu Sastra}

hide his feelings, that he was not interested in children and did not even plan to have children in his life.

The form of satire stated by the author is that although in general humans are creatures destined to settle down and have children, but the choice of living without children for the character is not something strange. He pointed out, how he could live together with other residents who mostly have many children in a large and simple apartment.

The events in the novel Orangorang Bloomington have iron or occult elements that are contrary to his expectations but have become his destiny. This is seen in the following quote.

“... dan ada juga yang jengkel karena di sini terlalu banyak anak, dan karena itu suasana menjadi gaduh, ada juga yang mengeluh karena anak-anak di sini nakal, sering berkelahi, dan merugikan anak mereka sendiri. Bahwa gedung ini jauh dari tempat umum, toh semua yang tinggal di sini mempunyai mobil. Bahwa mereka repot karena anak mereka, kan semua ini akibat mereka mempunyai anak" (Darma, 2004: 56).

"... and there are also those who are annoyed because there are too many children here, and because of that the atmosphere becomes noisy, there are also people who complain that children here are naughty, often fighting, and harming their own children. That this building is far from public places, yet all who live here have a car. That they are troublesome because of their children, this is all because they have children "(Darma, 2004: 56).

In the above quotation it is explained that the character lives in a simple apartment and is inhabited by families with many children. The condition of the apartment is always crowded and noisy so the situation in the apartment is not too comfortable. The location of apartments far from public places adds to the hassle of residents to carry out activities with children. The situation described in the quote above explains an irony of life. Having lots of children is a fate that must be accepted with all its risks, including all the hassle that must be faced.

The next aspect that appears in the collection of stories "Orang-orang Bloomington" is the spirit of playing which means the text or words are deliberately toyed with to create a dramatic atmosphere. The quotations below illustrate the play of words that give rise to the dramatic atmosphere built by the author.

"Hester Price, demikian nama perempuan yang kemudian menjadi istri saya, menyatakan bersedia saya 


\section{Jurnal Ilmu Sastra}

ajk kemana saja dan berbuat apa saja, tapi terkejut dan ketakutan ketika saya menjatuhkan keputusan saya untuk mengawininya. Dia menjerit. Dan untuk menggagalkan jeritannya dia menggigit bibirnya kuat-kuat, serta mencekik lehernya sehingga kedua biji matanya ajan meleset keluar. Sementara itu, warna wajahnya berubah, dan kalau saya tidak salah lihat, otot-otot di keningnya menjadi besar seperti kaki-kaki gajah. Kemudian dia mohon maaf dan lari sekuat tenaga menjauhi saya" (Darma, 2004: 83).

"Hester Price, as the name of the woman who later became my wife, stated that I would be willing to go anywhere and do anything, but was surprised and frightened when I dropped my decision to marry her. He screamed. And to thwart his scream he bit his lip firmly, and strangled his neck so that both of his eyes fell off. Meanwhile, the color of his face changed, and if I didn't see it wrong, the muscles in his forehead became large like elephant's legs. Then he apologizes and runs as hard as he can away from me "(Darma, 2004: 83).

The choice of words that are deliberately played in the above quote creates a dramatic element of a story. The depiction of the wife's reaction which was shocked when invited to marry by the character "I" gave a scary detail impression. The choice of words used by the author shows that the author wants to give an unusual description of a reaction in a conversation about marriage.

Camp is seen as a port of identity and possession. Camp becomes part of the tradition to mention something that has appeared and reappeared. Camp in contemporary architecture that acculturates old elements with new, advanced technological visualization or imaging. Camp is only to display the atmosphere as an impression maker that can be seen in the architectural style that uses beautiful decorative elements. This is evidenced in the quote below.

"Pada waktu fajar, Tulip Tree tampak bagaikan raksasa malas yang tidak mau bangun, pada waktu pagi tampak gagah, pada waktu siang tampak menantang keganasan matahari,pada waktu sore memantulkan cahaya matahari yang tenggelam melalui kaca-kaca jendelanya ke apartemen saya, dan pada waktu malam berkelap-kelip bagaikan seribu kunang-kunang di Manhattan. Sering saya membuangbuang waktu, melamun, memandang Tulip Tree. Sungguh kagum saya padanya. Apalagi kalau udara buruk, misalnya saja, pada waktu kabut melanda (Bloomington sering diliputi kabut, kadang-kadang 


\section{Jurnal Ilmu Sastra}

sampai beberapa hari) hujan, halilintar menggelegar, atau tornado mengancam. Dalam keadaan demikian Tulip Tree tampak remangremang, makin anggun, kuat, dan perkasa. Tidak ada satu halilintar punyang sanggup menggonjangkan gedung ini" (Darma, 2004: 200).

"At dawn, Tulip Tree looked like a lazy giant who did not want to wake up, in the morning it looked dashing, at noon it seemed to challenge the ferocity of the sun, in the afternoon it reflected sunlight sinking through the glass windows into my apartment, and at times the night twinkles like a thousand fireflies in Manhattan. Often I waste time, daydreaming, looking at Tulip Tree. I really admire him. Especially if the air is bad, for example, when the fog hits (Bloomington is often covered in fog, sometimes for several days) it rains, thunder booms, or tornadoes threaten. In this condition Tulip Tree looks dim, more graceful, strong, and powerful. There is no single thunderbolt capable of stretching this building "(Darma, 2004: 200).

The description of the Tulip Tree Building in the quotation above tries to describe the beauty of a building as part of the imaging of technological progress and the depiction of decorative elements and architectural styles. The beauty of the
Tulip Tree building is not described as a building full of decoration, but a depiction of a building that is luxurious, dashing, not easily collapsed or destroyed by the weather, and stands upright in the middle of Bloomington, so it is easily seen not from other apartments.

\section{Characteristics of Postmodernism in A} Collection of Novels Orang-orang Bloomington

The first postmodern characteristic seen from the novel "Orang-orang Bloomington" is the aspect of reducing admiration for science, capitalism and technology. Attitude anticipation of science and technology is seen in the quote below.

"Pintu lapis pertama sangat berat. Saya heran, mengapa orang tua yang saya cari, kalau memang dia tua, mau tinggal di sini, apalagi di tingkat lima belas. Bayangkan saja kalau listrik tiba-tiba mati pada waktu dia sedang berada dalam elevator. Mungkin dia bisa mati kehabisan udara. Bayangkan juga kalau pada suatu hari lonceng bahaya kebakaran dinyalakan. Semua harus turun melalui elevator. Sedangkan untuk keluar masuk gedung ini saja sudah berat. Lihat saja pintunya...." (Darma, 2004: 210-211). 


\section{Jurnal Ilmu Sastra}

"The first layer door is very heavy. I was surprised, why was the old man I was looking for, if indeed he was old, wanting to stay here, especially at level fifteen. Just imagine that electricity suddenly died when he was in an elevator. Maybe he could run out of air. Also imagine if one day the fire alarm bells are turned on. All must go down through the elevator. Whereas just going in and out of this building is already heavy. Just look at the door ... " (Darma, 2004: 210-211).

Based on the above quote, it can be seen the opinion of the author through the "I" character of the apartment building inhabited by Mrs. Elberhart is an old woman. The apartments are modern and well-equipped relative high-tech equipment to city life in America, it is still not ensure inhabitants live safely and comfortably. The author's perspective in interpreting an apartment facility in the city of Bloomington, America seems to indicate that sophisticated technology is not always in accordance with everyone's life.

The characteristic of shifting the dominance of whites in the western world appears in the story of Ny. Elberthart. The success of the "I" figure who migrated to the city of Bloomington can be found in the quote below.
"Saya tahu mengapa saya dianggap sebagai seorang Giman, selalu berhasil. Saya tidak pernah melalaikan apa yang dititahkan oleh guru saya. Pada waktu ujian, misalnya, saya tahu bahwa sebetulnya saya harus menjawab pertanyaan-pertanyaan dengan lebih baik. Tapi karena waktu saya terbatas, saya cukup menyelesaikan apa adanya, asal meloncati syarat untuk lulus. Demikian juga pada waktu menulis paper. Saya tahu bahwa masih dapat memperbaiki paper tersebut, mecoret kalimatkalimat yang tidak perlu, menambah argumentasi, merombak organisasi logika, dan sebagainya. Demikian juga skripsi saya, baik untuk gelar sarjana muda maupun sarjana. Saya yakin bahwa andaikata saya mau, saya dapat menyiapkan kedua skripsi tersebut untuk diterbitkan sebagai buku” (Darma, 2004: 202).

"I know why I am considered a Giman, always successful. I have never neglected what my teacher commanded. At the time of the exam, for example, I knew that I actually had to answer the questions better. But because my time is limited, I can just finish as is, as long as I skip the conditions to graduate. Likewise when writing a paper. I know that I can still improve the paper, write out unnecessary 


\section{Jurnal Ilmu Sastra}

sentences, add arguments, overhaul the organization of logic, and so on. Likewise my thesis, both for bachelor's and bachelor's degrees. I am sure that if I wanted to, I could prepare the two theses to be published as books "(Darma, 2004: 202).

The success of my character in the quotation above is an acknowledgment, that even though he is in the land of people, self-confidence, and the abilities possessed by the character are a reflection of the ability of the figure who deserves to be taken into account amid the domination of western people. The prevailing stereotypes that west dominate, are not vulgarly presented in the Orang-orang Bloomington novel. On the contrary, the success of the character in adapting to the natives illustrates that there is no boundary between the west and the east, even the weakness of the eastern nation is not visible to the main character.

The next characteristic of postmodernism that appears in the novel "Orang-orang Bloomington" is a description of the concern of one character with another character. "My" figure is very sensitive to the surrounding environment, easily touched by his feelings to see the suffering of others and that is done by giving care to his friends. This can be seen in the following quote.
"Ny. Seifert sudah memberitahu saya terang-terangan agar menjauhi Joshua. Tapi setiap kali Joshua dating dengan alasan ini dan itu, kenudian mengobrol panjang, saya tidak pernah mengusirnya. Dan akhirnya, dengan alasan ini dan itu, dia tidak mau pulang, lalu menginap di kamar saya. Saya juga tidak sampai hati menolaknya" (Darma, 2004: 30).

"Mrs. Seifert has told me openly to stay away from Joshua. But every time Joshua comes up with this and that reason, then chats, I never throw him out. And finally, for this and that reason, he didn't want to go home, then stayed in my room. I also don't want my heart to reject it "(Darma, 2004: 30).

The quote above tells the character of "me" who befriends the character Joshua, a sick and poor young man. Although his mother's spirit gave advice so that he was not too close to Joshua, still "I" did not have the heart to refuse Joshua's desire to come, even stay. A sense of solidarity towards friends and fear of injury, as well as concern for the character "I" are very visible in the quote above.

The next postmodern feature that appears in the Orang-orang Bloomington novel is to encourage the rise of oppressed groups, such as racial groups, excluded 


\section{Jurnal Ilmu Sastra}

social classes. These characteristics appear in the following quotations .

"Pasti ada sebebnya, "kata Melvin dengan nada tabah”. Mereka berkelahi terus bukan tanpa sebab. Mereka berkelahi karena diperlakukan tidak benar oleh orang lain. Kalau toh Martin ingin memonopoli mainan, satu-satunya sebab adalah bahwa kami ini orang melarat. Kami tidak bisa membelikan Martin mainan. Tapi tanggung jawab Mark, sebagai anak yang lebih tua, dia sudah saya beri kewajiban mengembalikan segala mainan kepada pemiliknya, dan sudah saya beri wewenang penuh kepadanya mengambil tindakan terhadap Martin. Bahwa Mark bertimdal agresif, tentu saja bukan tanpa sebab. Dia tidak suka dihina. Saya pun sering merestuinya untuk menyerang siapapun yang menghinanya tanpa alasan sehat dan sewenang-wenang" (Darma, 2004: 61).

"Definitely there was a lot," Melvin said with a tone of stoic ". They fight continuously not without cause. They fight because they are mistreated by others. If Martin wanted to monopolize toys anyway, the only reason was that we were destitute people. We can't buy Martin toys. But Mark's responsibility, as an older child, he gave me the obligation to return all toys to the owner, and I gave him full authority to take action against Martin. That Mark was aggressive, of course not without cause. He doesn't like to be insulted. I also often bless him to attack anyone who insults him for no reason healthy and arbitrary "(Darma, 2004: 61).

The quote above tells of a family that has two children with disadvantaged economic backgrounds. His father named Melvin Meek and his mother named Marion. Both work, so that their two children are left at home every day without parental supervision. Problems arise when both children are often seen as disturbing their neighbors. The sister often seizes other children's toys, damages people's cars by reason of wanting to take objects in them, and so on. As a father who wants to show that even though they are not a rich family, they still want to maintain dignity and do not want to be harassed because of their social status.

\section{CONCLUSION}

Postmodernism is a critical stream of views promoted by the previous era especially in modernism which is considered a failure and as a reaction to rebellion and criticism or the promise of modernism.

Based on the results of data analysis can be concluded as follows. The 


\section{Jurnal Ilmu Sastra}

postmodernism aspects revealed in Budi Darma's Orang-orang Bloomington novel include; (1) parody, (2) irony, (3) enthusiasm for playing which means the text or words are deliberately mocked to create a dramatic atmosphere, and (4) camp. The characteristics of postmodernism revealed in Budi Darma's Orang-orang Bloomington are as follows; 1) reducing admiration for science, capitalism and technology. 2) Shifting the dominance of whites in the western world, 3) a description of the concern of one character with another character, and 4) encouraging the rise of oppressed groups, such as racial groups, excluded social classes.

\section{REFERENCES}

Aceng, dkk. 2011. Filsafat Ilmu Lanjutan. Jakarta: Prenada Meda Grup.

Darma, Budi. 2004. Orang-orang Bloomington. Jakarta: Metafora Intermedia Indonesia.

Djojosuroto, Kinayati. 2002. Analisis

Teks Sastra dan Pengajarannya. Yogyakarta: Pustaka.
Hutcheon, Linda. 2004. Politik Postmodernisme: Translated into Indonesian by Apri Danarto. Yogyakarta: Penerbit Jendela.

Lyotard, J. F. 1984. The Postmodern Condition: a Report on Knowledge. Manchester Manchester University Press.

Muzairi. 2009. Filsafat umum. Yogyakarta: Teras.

Nath, Shanjendu. 2014. The Concept of Reality from Postmodern Perspectives. In Journal of Business Management and Social Science Research (JBM\&SSR), 3(5), 26-30. View at Google Scholar.

Sarup, Madan. 2007. Posstrukturalisme \& Postmodernisme. Yogyakarta: Jendela

Setiawan, Johan. 2018. Pemikiran Postmodernisme dan Pandangannya terhadap Ilmu Pengetahuan. Jurnal Filsafat, 28(1), 25-46. View at Google Scholar.

Wellek, Rene, Warren, Austin. 1995. Teori kesusastraan: Translated into Indonesia by Melani Budianta. Jakarta: Gramedia Pustaka Utama. 